\title{
Accelerate Project Activities Of Systematic Land Complete Registration (PTSL) In Tigajuru Village, Mayong Subdistrict, Jepara District
}

\begin{abstract}
Jawad Fadli ${ }^{1}$ and Umar Ma'ruf ${ }^{2}$
Abstract. This study aims to Investigate the implementation of PTSL activities in Tigajuru Village, Mayong Subdistrict, Jepara District and find out the barriers and solutions in the implementation of PTSL activities in Tigajuru Village, Mayong Subdistrict, Jepara District.

The method used in this research is the Socio-Juridical. Data collection techniques using the data of primary and secondary data. Data were analyzed using qualitative analysis in order to obtain clarity on the issues discussed and subsequently prepared as a thesis of a scientific nature.

Results of analysis showed that the stages of implementation of land registration systematically full of determining the location, the establishment of adjudication committee, counseling, the establishment of a task force of data collectors Juridical data collection Juridical, the data processing Juridical and evidentiary rights, edaphology and measurement, announcement, publishing certificate, and the final stage of delivery of certificates. Implementation of Land Registration of Property Rights Systematically full compliance with the Regulation of the Minister of ATR / BPN No. 1 of 2017 in Jepara, it is stipulated in the Regulation of the Minister of ATR / BPN No. 1 Of 2017 on the Acceleration of the Implementation of Systematic Land Complete Registration.

Keywords: Accelerate Project; PTSL; Notary.
\end{abstract}

\section{Introduction}

Earth, water and air space as well as all natural resources contained in it is a gift from God Almighty to all the people of Indonesia and therefore, it should use the function of the earth, air and space and all what is contained in it is intended to Achieve the greatest prosperity of all the people of Indonesia.

Soil is the surface of the earth the which is where humans live and expand and seek livelihood through as the dwelling place when the die, G. Kartasaputra stated the importance of soil for human beings because human life can not be separated entirely from the ground. ${ }^{3}$ Thus the importance of soil for human life, it is not surprising that every human being wants to have or hang, resulting in the emergence of land issues, which often lead to disputes.

In 2017 based on Regulation of the Minister of Agrarian and Spatial Planning / Head of National Land Agency of the Republic of Indonesia No. 1 of 2017, was composed of Program Accelerating the Implementation of Systematic Land Complete Registration. PTSL is activities organized by government in the field land in general and in registration field land in particular, which the form of the certification land held simultaneously together (Mass) and settlement of disputes ground strategic nature.

Jepara District Land Office as one of the Land Office in Central Java in 2017 has implemented the Land Registry Implementation Program Complete Integrated Systems

\footnotetext{
${ }^{1}$ Students Master of Notary Law, Unissula, e-mail : jawadfadly7@gmail.com

2 Faculty of Law UNISSULA Semarang

${ }^{3}$ G. Kartasaputra, Hukum Tanah Jaminan Bagi Keberhasilan Pendayagunaan Tanah, PT. Raja grafindo Persada, Jakarta,1991, p. 9.
} 
(PTSL) that have been planned with the support of funds from the central government to the State Budget (APBN abbreviated) with number of fields soil already determined / limited according Table of Contents Budget implementation (Hereinafter referred to as DIPA). In the of 2017 the district of Jepara obtain PTSL 40,000 (forty thousand) parcel of land in the 20 (twenty) districts, which is in Batangan, Cluwak, Dukuhseti, Gabus, Gembong, Jaken, Juwana, Kayen, Mayong, Margoyoso, Jepara, Mayong, Sukolio, Tambakromo, Tayu, Tlogowungu, Trangkil, Wedarijaksa, Winong, Tayu.

From a total of 40,000 (forty thousand) PTSL divided in two Phase PTSL, in the first phase of 15,000 (fifteen thousand) and the second phase of 25,000 (twenty five thousand) in Jepara district. One of the villagers who get PTSL project is Tigajuru village. Tigajuru village get a ration of 200 plots of land in PTSL. The village is classified as extremely dense population of the state of the majority community and the educated middle-weak economy. ${ }^{4}$ Tigajuru selected villages researchers because of the report in 2017 PTSL Tigajuru nicest villages in making the report PTSL.

remember program implementation PTSL is Land Office activities related to by Agencies Other (Government Jepara district, sub-district and the Village Head The local as well as Applicant / community village where implementation PTSL program) then success required a coordination and good performance. Based on the results of the review report of the nicest is the village Tigajuru penuis get the information from the interview with Nur Rido one measuring officers in BPN Jepara. ${ }^{5}$ Therefore, to investigate the implementation of the PTSL in Tigajuru village necessary for the preparation of the thesis, with the title: " Accelerate Project Activities Of Systematic Land Complete Registration (PTSL) In Tigajuru Village, Mayong Subdistrict, Jepara District".

Based on the description above, this study will answer the formulation of the problem: 1) How is the implementation of PTSL activities in the Tigajuru village, Mayong subdistrict, Jepara district?; 2) What are the obstacles and solutions in the implementation of PTSL activities in the Tigajuru village, Mayong sub-district, Jepara district?

\section{Research methods}

This research is a legal research with empirical approach or regular juridical also known as the Juridical Sociological. ${ }^{6}$ According to his level, the study was specified as descriptive analytical research. Sampling technics is purposive sampling. ${ }^{7}$ Method collection data used: Data Primary form of observations and interviews, secondary data in the form of primary legal materials and secondary law.

Method data used in the analysis This research is qualitative analysis, which is a way of analysis of the research results generate analytical descriptive data, ie data is expressed by respondents written or oral, and also behavior behavior real, researched and studied as something intact. ${ }^{8}$

\footnotetext{
${ }^{4}$ Saman, Personal Interview, Head of Tigajuru village, Mayong sub-district, Jepara district, 23 September 2017.

${ }^{5}$ Nur Rido, Personal Interview, Officer Measure Jepara District Land Office, 23 September 2017.

${ }^{6}$ Mukti Fajar ND dan Yulianto Achmad, Dualisme Penelitian Hukum Normatif \& Empiris, Pustaka Pelajar, Yogyakarta, 2010, p 47.

7 SoerjonoSoekanto, Penganta Penelitian Hukum, Universitas Indonesia Press, Jakarta,1986, p.196.

8 Ibid, p.192.
} 


\section{Results and Discussion}

\subsection{Implementation PTSL in the Tigajuru village, Mayong sub-district, Jepara district.}

In order to provide legal certainty to the holders of land in this regulation are given confirmation of the extent to which the strength of evidence the certificate, which is expressed as a strong evidentiary tool by BAL. For that granted provided that during the juridical data contained in the certificate must be accepted as true, either in everyday law-making as well as in the dispute in court. Throughout such data in accordance with what is stated in the measurement certificate and land book (Article 32 paragraph 1 of Government Regulation No. 24 of 1997), that person can not claim land that has been certified on behalf of the person or other legal entity, if for 5 ( five) years since the issuance of the certificate that he did not file a lawsuit in court. ${ }^{9}$

There are programs of the central government in 2017 is related to the field of land on the granting of certificates to the public by way of registration of land systematically and then issue the Regulation of the Minister of Agrarian and Spatial Planning / Head of National Land Agency of the Republic of Indonesia Number 1 Of 2017 on the Acceleration of the Land Registration Systematic Detailed be guidelines in the implementation of this program. In Article 1 (1) explained that the Systematic Land Complete Registry hereinafter abbreviated PTSL is the activity of the Land Registry for the first time carried out simultaneously for all objects Land Registration in the entire territory of the Republic of Indonesia in the territory of the village / village or any other name that is level with the that, which involves the collection and determination of the truth of physical data and juridical data regarding one or more objects Land Registry for registration purposes. The object PTSL cover the entire plot without exception, both plots were no rights to the land or parcels of land rights, both the land asset / regional government, the land of the State Owned Enterprises / Regional Owned Enterprises, the village land, the State Land , indigenous and tribal peoples lands, forests, land reform object, land resettlement, and other parcels.

PTSL implementation was carried from village to village in the district and village-byvillage in the district and village-by-village in the urban region that includes all parcels of land throughout the territory of the Republic of Indonesia. Pursuant to Article 2 Objectives of the program PTSL is to accelerate the provision of legal certainty and legal protection of Land society as surely, simple, fast, smooth, safe, fair, equitable and open and accountable, so as to improve the welfare and prosperity of society and the country's economy, as well as reduce and prevent disputes and conflict over land.

This PTSL implementation phases carried out in accordance with the object, the subject, the right base, and process and financing activities PTSL program. For efficiency and effectiveness of the implementation of this PTSL then head Land Office set a target deployment PTSL concentrated in a few districts / cities in the province gradually, taking into account and considering the availability of human resources that exist in the environment of the Land Office and the Regional Office of BPN. Article 19 paragraph (1) BAL mandates that in order to ensure legal certainty by the Government held land registration throughout the territory of the Republic of Indonesia in accordance with the provisions stipulated in Government Regulation. Provision of legal certainty and the protection of land rights law a fair and equitable society and promote economic growth

\footnotetext{
${ }^{9}$ Ismaya Samun, 2011, Pengantar Hukum Agraria, Cetakan Pertama Graha Ilmu, Yogyakarta, 2011, p. 99.
} 
in general and the people's economy in particular, need to be accelerated so that the complete land registration throughout the territory of the Republic of Indonesia. To achieve this, the Ministry of Agricultural and Spatial Planning / Head of National Land Agency Regulation of Minister of Agrarian and Spatial Planning / Head of National Land Agency of the Republic No. 12 Of 2017 on the Acceleration of Systematic Land Complete Registration. Implementation of this PTSL implemented through two (2) approaches: The Ministry of Agricultural and Spatial Planning / Head of National Land Agency Regulation of Minister of Agrarian and Spatial Planning / Head of National Land Agency of the Republic No. 12 Of 2017 on the Acceleration of Systematic Land Complete Registration. Implementation of this PTSL implemented through two (2) approaches: The Ministry of Agricultural and Spatial Planning / Head of National Land Agency Regulation of Minister of Agrarian and Spatial Planning / Head of National Land Agency of the Republic No. 12 Of 2017 on the Acceleration of Systematic Land Complete Registration. Implementation of this PTSL implemented through two (2) approaches:

- Full systematically village / sub PTSL by selecting a number of villages / villages which number of parcels that have not been registered is low and / or which may be financed by the existing budget; or

- City / county PTSL for city / county that the number of parcels that have not been registered less than 10,000 parcels of land and / or a number of specific plots of land that can be financed with the existing budget; Sporadic flocking towards a systematic and complete gradually from village to village and village-by-village in the sub-districts in each city / county.

The program of the central government which Systematic Land Complete Registration abbreviated to PTSL, in 2017 the Government will allot five million certificates throughout the territory of the Republic of Indonesia. Minister of Agrarian Spatial / National Land Agency Sofyan Djalil stated that the Homeland is just $46 \%$ (forty-six percent were certified, while $54 \%$ (fifty-four per cent) have not been certified, it is behind the provision of those certificates, there is a program government that began in $2017 .{ }^{10}$

The registration of property rights to land are systematically complete with the enactment of regulations and spatial agrarian minister / head of the national land agency number 1 in 2017. Activity systematic land Complete Registration Jepara implemented for the first time, given the many people in Jepara district has not registered the to the land. Systematic Land Registration Event Complete an agenda that has been set by the Land Office Jepara District, to help people register their land rights. Following the phaseconversion stages are conducted through the Accelerating Implementation Activity Systematic Land Complete Registration.

- Determination of location;

- The formation of the Adjudication Committee was formed on 18 January 2017: (a) Adjudication; (b) The composition of the Adjudication Committee,

- Counseling;

- Task Force Juridical Data Collectors;

- Juridical Data Collection;

- Juridical data processing and Evidence Rights;

- Soil examination and measurement;

- Announcement;

- Issuance of Certificates;

10 https://jatengprov.go.id/berita-utama/prona-bukan-bagi-bagi-sertifikat accessed July 11, 2018. 
- Submission of Certificate handover certificate is the last step of a series of Systematic Land Complete Registration conducted in the Accelerate Project Activities Of Systematic Land Complete Registration (PTSL) In Tigajuru Village, Mayong Subdistrict, Jepara District.

Regulation of the Minister of Agrarian and Spatial Planning / Head of National Land Agency of the Republic No. 1 Of 2017 on the Acceleration of Systematic Land Complete Registration is evident that the application of those principles. In writing contained in Article 2 paragraph (2), which essentially says that the program of this government in the form of the Systematic Land Complete Registry undertaken to provide legal certainty and legal protection of land rights to the public exactly which form of the certificate, with the process simple fast smooth, safe, fair, equitable and open to everyone without exception to meet the requirements specified in peratura law and accountability which the liability of the organizers of this program.

Accountability of these PTSL activities with their report on the implementation of activities when there is a problem in the implementation of PTSL and after PTSL completed. As for the report when there is a problem made by Chairman of the Adjudication Committee PTSL to the head of the Land Office with a copy of the Director General of Legal Relations and Coconut Keagrarian BPN Regional Office. While sat PTSL report completed in stages and periodically from the Land Office, the Head of BPN Regional Office, and Minister for using the application Quality Control System (SKMPP).

\subsection{Obstacles and solutions in the implementation of activities in the Accelerate Project Activities Of Systematic Land Complete Registration (PTSL) In Tigajuru Village, Mayong Subdistrict, Jepara District}

Barriers that occur in the implementation of land titles registration is complete systematic aforementioned Jepara District Land Office barriers that occur from the Land Office Jepara District comes from:

- Budgets

The budget question is a useful budget for the implementation of activities Systematic Land Complete Registration. In Article 15 paragraph (1) to (4) Regulation No. 1 of 2017 is explained on Sources of Financing, in this case the activities of the Land Registry Systematic Full Of 2017 budget only comes from the District Land Office Pati financed by the state budget there is no other party help so that the budget is used only limited to the scope of work of the Land Office Pati. The budget problems have an impact on the activities supported by people around the village in a filing that included the Land of Conduct Awareness Society (POKMASDARTIBNAH) but the surrounding community to call with any community groups ${ }^{11}$. With a limited budget then the impact on the charges so that in the event the Systematic Land Complete Registry 2017 the no correspondence between what's happening on the field with Article 14 of Regulation No. 1 Of 2017 that is mentioned in the outline of activity Systematic Land Complete Registry not charged a fee for registration land is a government obligation. Even so Pati District Land Office in 2018 in the implementation of the Land Complete Registration Systematic has no source of financing of local government, there may be a separate budget so Pokmas help for filing for the community.

In the study the authors interviewed an employee of the Land Office Pati, Joko Purwanto as chief coordinator of activities of the Systematic Land Complete Registry

\footnotetext{
11 Saman, Personal Interview, village head Sukobubuk Margorejo District of Pati regency, July 23, 2017.
} 
2017 in the interview he said that the announcement period has registered a land in Government Regulation No. 24 of 1997 on the Land Registry for registration of a systematic 30 weekdays while to Regulation No. 1 Of 2017 for 14 days of work, which is so the problem is the land registry of systematic premises the Ministerial Regulation No. 1 Of 2017 thorough sector in a village just given 14 days while PRONA given the same time but sporadically not thorough, and he said that the Ministerial Regulation No. 1 in 2017 could defeat the Government Regulation No. 24 of 1997 in terms of the announcement period. ${ }^{12}$

- Measurement

Measurement is meant is before the Systematic Land Complete Registry in Margorejo District more precisely in the village Sukobubuk, before any measurements were made of the Gadjah Mada University (UGM) in Yogyakarta through Real Working Lecture (KKN), but the result of the measurement was inaccurate does not fit with what is in the field so that there should be a reassessment of the BPN.

- Legal event of death

Registration of land that has been carried out measurements and recorded on file by the adjudication committee assisted by a task force of physical and juridical should be revised or double-checked back due to the legal events of death, due to their death before the certificate so, then in such deaths have occurred inheritance from the heir to the experts inheritance that land which was originally one field into several fields, so the adjudication committee and officers must re-measure measuring such fields as complete a systematic land registration, should be a thorough one village without exception.

In case of the death of the certification persists like others, but if you want a certificate on inheritance HLI then after finished registration certificate, back in the Land Office for enrollment solution for his Heir on condition that there is a death certificate and statement of Heirs

- Device hamlet

Activity Systematic Land Complete Registry held by the District Land Office Pati really need support from the hamlet as a bridge between the Land Office with the community as a participant, but in the village of Sukobubuk there are Also devices hamlet inactive mainly is his hamlet should Participate in this activity, especially land surveying while underway.

- Community

Systematic Land Complete Registration activities needed enthusiasm of the community, in the community, especially in the hamlet Kemirikebo feel difficulty in filling application for registration of land and the lack of assistance filling the blank and should be assisted by POKMA. Solutions to these problems filling of forms filled out by the Village. The problems of society are the obstacles other woods are a society that has ground the result of inheritance has several brothers and sisters who also acquired as heir to the care of the land registration must be approved by other heir, while heir others do not exist in a region, so if it had to wait for approval or consent letters from expert who live outside the city.

Barriers that occur in the implementation of Systematic Land Complete Registration in Jepara district has some of the barriers in terms of the Land Office, Device village, community, and on things that other unforeseen.

\footnotetext{
12 Joko Purwanto, Personal Interview, Coordinator PTSL Pati District Land Office, June 23, 2018.
} 


\section{Closing}

\subsection{Conclusion}

- Based on the results of the research, the stages of implementation of land registration systematically full of determining the location, the establishment of adjudication committee, counseling, the establishment of a task force data collectors juridical, data collection juridical, data processing juridical and evidentiary rights, edaphology and measurement, announcement, publishing certificate and the last stage of delivery of certificates then Implementation Registration Property Rights to Land Systematically full compliance with the Regulation of the Minister of Agrarian and Spatial Planning / National Land Agency Number 1 Of 2017 in Jepara, it is stipulated in the Regulation of the Minister of Agrarian and Spatial / Land Agency national No. 1 of 2017 on Accelerating the Implementation of Systematic Land Complete Registration the Article 3 paragraph (3) provides that: accelerated implementation of Systematic Land Complete Registration is done in phases:

- Determination of the location of the acceleration of activities Systematic Land Complete Registration;

- Adjudication Formation Acceleration;

- Physical data collection and data in the field Juridical land;

- Proof rights and bookkeeping Rights to Land;

- Issuance of certificates of land rights, for those who qualify Thirty respondents in Hamlet Kemirikebo who register ownership of the land has to register with the steps described above, and the activities of Systematic Land Complete Registration 2017 new Tigajuru Village until Stage announcement.

- Barriers that occur in the implementation of registration of land rights are systematically complete in Jepara district has some of the barriers in terms of the Land Office, Device hamlets and communities,

- Land Office clerk having problems with a lack of measurement, the measuring solution by adding clerk at the Land Office.

- Hamlet constrained devices as miscommunication with measuring officer of the Land Office, the solution with confirmation to the clerk when measuring the Land Office could not accompany the measurement in the village.

- People experience problems related to charging blank PTSL filing requirements, the solution filling the blank filled by the Village.

\subsection{Suggestion}

- To the Central Government in this case the Ministry of ATR / BPN should increase the budget implementation officer PTSL and add BPN because with the PTSL program make BPN staff in performing their duties and additional budget is used to cover unexpected costs in the implementation of PTSL.

- To BPN Jepara district should improve employee performance in program implementation PTSL of Jepara.

- Tigajuru Village Government should be more pro-active and provide support for the implementation of the program PTSL to contribute to help the officer BPN.

- Tigajuru village residents should play an active role and take advantage PTSL program so that implementation can proceed smoothly PTSL and citizens obtain redress in the form of land ownership certificates to provide legal certainty for owner. 


\section{Bibliography}

\section{Books}

[1] G. Kartasaputra, 1991, Hukum Tanah Jaminan Bagi Keberhasilan Pendayagunaan Tanah, PT. Raja grafindo Persada, Jakarta.

[2] Ismaya Samun, 2011, Pengantar Hukum Agraria, First Publishing, Graha Ilmu, Yogyakarta, 2011

[3] Muktin Fajar ND dan Yulianto Achmad, 2010,Dualisme Penelitian Hukum Normatif \& Empiris, Pustaka Pelajar, Yogyakarta, 2010

[4] SoerjonoSoekanto, 1986, Penganta Penelitian Hukum, Universitas Indonesia Press, Jakarta.

\section{Legislation}

[1] Act No. 5 of 1960 About the Basic Regulation of Agrarian (Basic Agrarian Law);

[2] Government Regulation No. 24 of 1997 on Land Registration Government Regulation is an implementation of Article 19 of the Basic Agrarian Law;

[3] Regulation of the Minister of Agrarian and Spatial Number 28 Of 2016 on the Acceleration of the National Program for Agricultural Through Systematic Land Registration.

[4] Regulation of the Minister of Agrarian and Spatial Planning No. 35 of 2016 on Accelerating the Implementation of Systematic Land Complete Registration.

[5] Regulation of the Minister of Agrarian and Spatial Planning No. 1 of 2017 on Accelerating the Implementation of Systematic Land Complete Registration.

\section{Internet}

https://jatengprov.go.id/berita-utama/prona-bukan-bagi-bagi-sertifikat accessed July $\underline{11,2018 .}$. 